\title{
An Analysis of the HRGA Department Process
}

\author{
Teofilus Nugraha Setiadarma ${ }^{1}$, Benedictus Rahardjo ${ }^{2 *}$ \\ ${ }_{1,2}$ Department of Industrial Engineering, Petra Christian University, Jl. Siwalankerto 121-131, Surabaya 60236, Indonesia \\ *beniapeter. petra.ac.id
}

\begin{abstract}
This study provided an analysis of HRGA Department processes at XYZ Company. The KPIs of the HRGA Department at XYZ Company has been ineffectively and inefficiently processed since 2017 till the first quartile of 2018. This study, therefore, aims to provide an analysis of the processes through the Recruitment, Training \& Development, and Personnel Administration, with the fishbone diagram used to determine the main and root causes of the problems. The result showed that the processes were ineffective and inefficient because the company's working instruction partially complied, lacked employee leadership, and the organizational structure has not been updated in accordance with its development.
\end{abstract}

Keywords: HRD, HRGA, recruitment, personnel administration, training and development, fishbone diagram.

\section{Introduction}

Human Resources (HR) becomes the most important asset in the organization (Susiawan and Muhid, [1]). It is on the grounds that HR is one of the sources which drives the business operations of a company. HR must be managed effectively and efficiently. Human Resource management is related with the profitability of the company (Paul and Anantharaman, [2]). Therefore, a good management will affect the company's profit. HR management is done by a department named Human Resource Department (HRD). The task of HRD is to manage skills, procurement, skills development and employees walfare (Bartlett, [3]). The effective and efficient of HR operations management is decided by HRD, so that its processes need to be carried out effectively and efficiently as well.

$\mathrm{XYZ}$ company is one of the multinational companies engaged in manufacturing process. XYZ company has an employee management department that divided in two parts, the Human Resource (HR) and General Affairs (GA) Department. HRGA Department has four sections namely recruitment, training and development, personnel administration and industrial relations. Each section has an HRD task starting from the procurement, development and welfare of employees.

Each HRGA section also has KPIs related to the task performed. The KPI is useful for measuring the performance. In the year of 2017, for instance, the achievement of HRGA department on KPI recruitment was only resulted in $71 \%$, implies failed to accomplish the targeted number which is 95\%. Failure in achieving the KPI indicates that the process has not been run effectively and efficiently. Therefore, the process that cause in the disappointment of accomplishing KPI needs to be profoundly analyzed. The analysis process will find the root of the existing problem so that relevant solutions could be developed. This will increase the efficiency and effectiveness of the process specifically in the HRGA Department and likewise increase the company's performance.

\section{Research Methods}

This part will discuss about all the methods used in solving problems. A brief discussion of the department will also be explained in this section.

\subsection{HRGA Department}

HRGA is a department that regulates human resources, and everything related to legal and corporate relations. According to Rao [3], HRGA Department is a management related to planning, organizing, directing, and controlling as well as operational functions such as procurement, development, compensation, integration and maintenance. Each function is contained in each section.

\subsection{Recruitment}

Recruitment is a process of finding job applicants through motivation, skills and knowledge to cover the shortage or needs in personnel planning (Simamora, [4]). The process starts with the request process until the interview process. Several things that must be considered in the recruitment process are physical condition, education, skills, attitude, user, lead time and budget

\subsection{Training and Development}

Training is a process to develop knowledge and skill so as employees or workers can perform their duties well in accordance with company standards (Mangkuprawira, [5]). The training process is useful for employees, companies and consumers where employees will get or improve the skills that give impact on rising productivity. A rising productivity will increase the profit and reduce defects.

\subsection{Personnel Administration}

The administration is an administrative action in which the activity of arranging a description systematically and recording with the intention of obtaining a core of the information (Purwanto, [6]). The entire process of data collection, registration, attendance and many things are done by this section.

\subsection{Key Performance Indicator (KPI)}

KPI is a tool to measure employee performance. KPI must be approved by both the employee and the top management. KPI must be relevant to the responsibilities of the employee. According to Parmenter [7], there are seven characteristics of KPI namely, 
- KPI writing is not only in financial aspect but also in volume denomination.

- $\quad$ KPI must be measured periodically e.g. every 6 months, 4 months, etc.

- KPI implementation must be fully committed from top management to employee.

- Employees need to be well informed of the measurements and corrective actions that need to be taken.

- KPI must relates the individual responsibilities to the team.

- KPI measurements must have impact on the company's target achievement.

- KPI must has a positive impact on the organization relatively.

The importance of setting KPI is emphasized by Kowal [13], to determine the stage of objectives completion. Some successful applications of KPI determination are in the energy sector [13], aviation area [14], automotive sector [15], and even in a Cyber-Physical production system, which one of the fourth industrial revolution approach [16].

\subsection{Fishbone Diagram}

Fishbone Diagram (Ishikawa Diagram) is a tool that used to improve the quality of a process. This diagram is called fishbone because it resembles as a fishbone. (Tauge, [8]). The diagram forms a branch of a fishbone to write the root of the problem. The root of the ploblem is classified into six parts: man, method, measurement, machine, materials and environment.

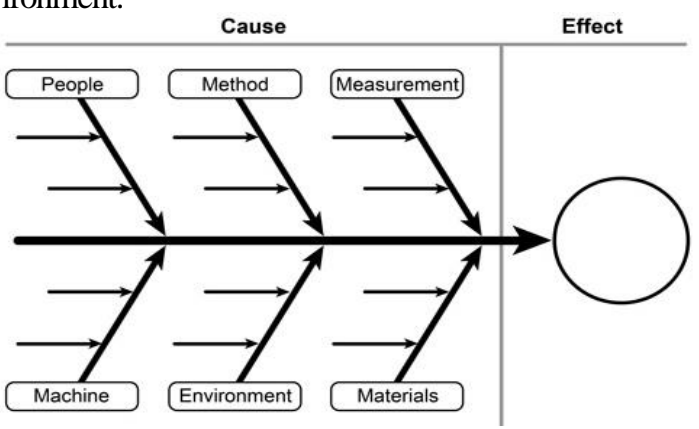

Figure 1. Fishbone Diagram Example

\subsection{Research Flowchart}

The flow of research can be seen in Figure 2.

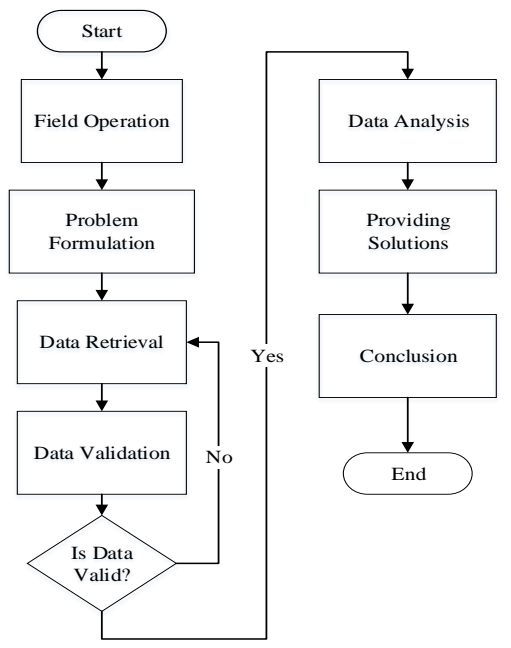

Figure 2. Research Flowchart
Basically, this research adopts a qualitative method based on the observation and interview for data collection. The research steps are as follows:

- Field Observation: Observation is used to know the process with respect to the tasks performed by the HRGA Department. Observation is done in two ways that are observing as an outsider company and doing processes directly.

- Problem Formulation: The process of determining problems at the HRGA Department where problems occur in the inefficiency and ineffectiveness of the process that cause the failed KPI.

- Data retrieval: Data were taken in accordance to the problem. Two ways of data collection are having an interview with the employee and collecting data on the field.

- Validation: The data validation process is done by ensuring directly to the manager of each section.

- Data Analysis: The analysis was performed by using a fishbone diagram to find the root of the problem and the relevant solution.

- Providing Solutions: The solution given is in accordance with the root of the problem and might be applied to the company. Solutions are derived from a depth analytical thinking of the author based on previous professional experience. Verification of the proposed solutions was already done with the section manager, who have authority to be implemented.

- Conclusion: A phase to summarize the overall process, problems and solutions for the company.

\section{Results and Discussion}

At first, the process for each section of the HRGA Department is briefly introduced. Observations were done only in three sections: recruitment, training and development, and personnel administration. Each section will be analyzed through the result of KPIs in 2017 and 2018. The analysis and solutions were given in accordance with the condition of XYZ company. The KPI calculations are done every three months starting from December.

\subsection{Recruitment Analysis and Solution}

The process of recruitment starts from Manpower Planning (MPP) and Manpower Request (MPR), candidate search and interview process. The candidate and interview process are conducted by company staff and assisted by subcontracting companies. One of the main recruitments KPI is the lead time of the recruitment process is minimum $95 \%$ which means staff must recruit the candidate minimum $95 \%$ on time from all request. KPI data is taken starting from the calculation of the end of 2017 to April 2018.

Table 1. Recruitment KPI

\begin{tabular}{llll}
\hline Quartile & Year & Result & Status \\
\hline Q1-Q4 & 2017 & $71 \%$ & Not Achieved \\
Q1 & 2018 & $100 \%$ & Achieved \\
Q2 (First two months) & 2018 & $83 \%$ & Not Achieved \\
\hline
\end{tabular}

In 2017, the KPI is about $71 \%$, implies that KPI is not achieved. Q1 in 2018 reached 100\% while in Q2 in the first 


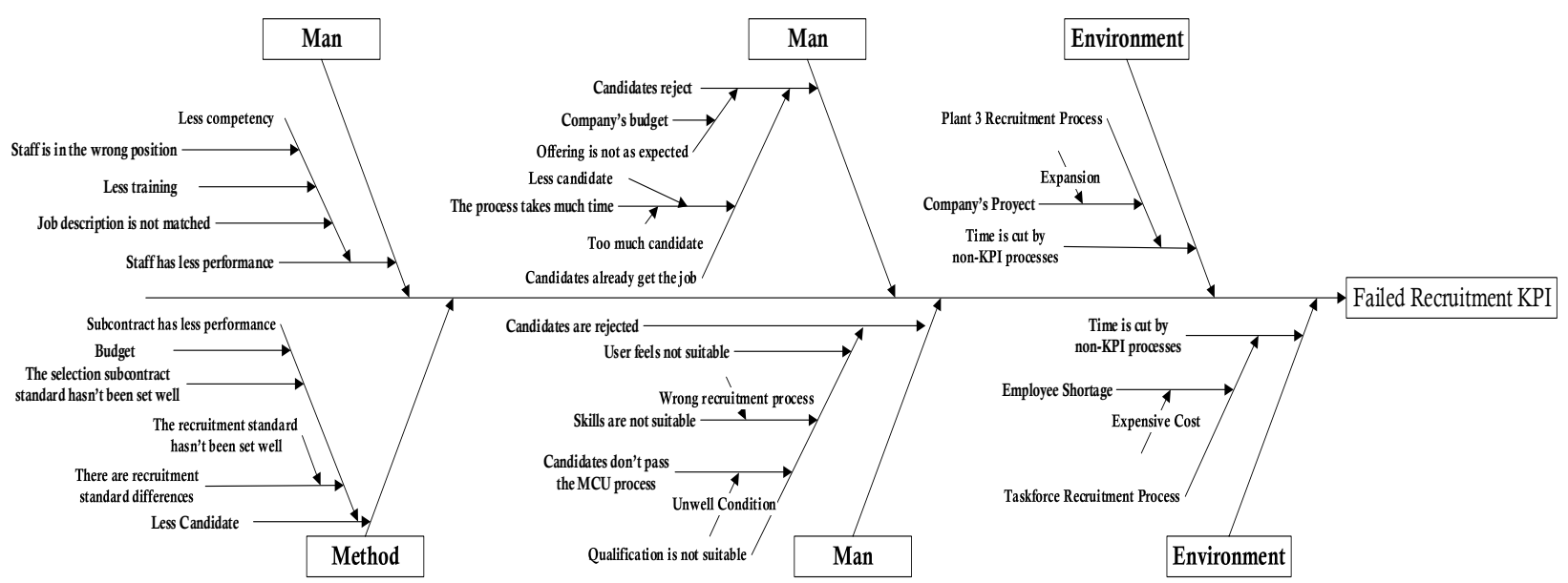

Figure 3. Recruitment Fishbone Diagram

two months decreased to $83 \%$. If the third month in Q2 is $100 \%$, the KPI is still not achieved by a margin of $0.7 \%$. An analysis needs to be done by using a fishbone diagram so that the KPI in 2018 could be achieved.

Figure 3 shows some causes which take effect on the failure in achieving KPI, obtained from the results of observation and brainstorming with employees in the department section. There are three main categories of causes, such as man (candidate and employee), method (subcontract) and environment (project).

- Candidates: Some candidates reject the offer because of some reasons, such as salary offerings are not as expected, the candidate has already accepted another job during the recruitment process and other unexpected things (parent factor, distance, etc.). Candidates get another job because the user takes too much time due to the high number of candidates or the comparison process among the candidates. Candidates are rejected as due to inappropriate qualifications where qualifications were not identified at the time of the interview.

- Employees: The competencies required in recruitment positions are not suitable and the employees have less recruitment competencies. This is on the grounds that the rolling process of employees at the HRGA Department, lack of training and competency needs has not yet emerged fully in the job description.

- Subcontracting: There is a standard difference in the recruitment process so that the process does not meet company standards. This is because there is no clear subcontracting standard yet.

- Project: The company's project lead to an employee recruitment process that is outside of the KPI calculation. The process is done for the new plant and the taskforce. The recruitment time is wasted due to these non-KPI projects.

The result of the analysis shows that KPI is not achieved due to the internal party of the external department. Therefore, the solutions that can be given are as follows:

- Subcontract Standard and Qualification Evaluation: Subcontracting selection standards should be clear so that subcontracting selection will conform to company standards. Existing subcontracts need to be assessed the same as the subcontracting standard. According to Jamila [9], there are four criterias: recruitment quality, punctuality, service process and recruitment costs. Each of these criteria is defined according to company needs and given the weight. The standard example can be seen in Table 2.

Table 2. Subcontract Selection Criteria Example

\begin{tabular}{ll}
\hline Subcontract Standart & Weight \\
\hline Recruitment Quality & 0.4 \\
Punctuality & 0.3 \\
Service Process & 0.2 \\
Recruitment Costs & 0.1 \\
\hline
\end{tabular}

- Detailed Data Capture Process: The recording process starts from the beginning to the end. This is done so that companies know the failure percentage of the recruitment process for each stage. The results are useful for more detailed analysis of the recruitment process. The process can be done by using information systems that are integrated with other departments and sections.

- Employee Competency: Each employee of HRGA Department needs to be assessed. The competencies should be clarified through the development of job descriptions that fit the company's circumstances. Assessment results will describe the competency of each employee in order that the lack of competency could be identified with the intention of the employee will be given further training in accordance with the required competencies.

\subsection{Training and Development Analysis and Solution}

This section has responsibilities in dealing with employee training and development including new employees. The training process has a variety of models starting with field practice, classroom training and assignment. The training is held according to the required competencies frin both the request and the result of the assessment whereby this section has one project named Individual Development Program (IDP). One of the main KPIs in this section is IDPs reach targets. The IDP KPI is divided into two, technical with the 
minimum of each quartile $5 \%, 25 \%, 75 \%, 100 \%$ and nontechnical with the minimum of $0 \%, 10 \%, 35 \%, 50 \%$, respectively.

Table 3. Training and Development KPI

\begin{tabular}{ccccl}
\hline \multirow{2}{*}{ Quartile } & Year & \multicolumn{2}{c}{ Result } & Status \\
\cline { 3 - 4 } & & Technical & $\begin{array}{c}\text { Non- } \\
\text { Technical }\end{array}$ & \\
\hline Q1-Q4 & 2017 & $52.9 \%$ & $16.9 \%$ & Not Achieved \\
Q1 & 2018 & $5 \%$ & $2 \%$ & Achieved \\
Q2 & 2018 & $8 \%$ & $3 \%$ & Not Achieved \\
\hline
\end{tabular}

KPI in 2017 contrast enormously from the limits that have been determined. In the first quartile, the KPI is achieved. However, in the first two months of the second quartile, the KPI is not achieved. The minimum result on the second quartile are $25 \%$ and $10 \%$. The remaining second quartile is one month while the percentage movement is so small that the $\mathrm{KPI}$ is indicated to be unreachable in the second quartile. If this continues to happen then the KPI in 2018 has a very big possibility to not be achieved again therefore analysis needs to be done in this process.

Figure 4 depicts the fishbone diagram of the failure on accomplishing training and development KPI. There are two categories of causes namely man and method. Man is related to trainees, trainers and supervisions. The method category is related to Working Instruction (WI) and the daily processes.

- Trainees: some trainees are absent due to illness, forbidden and forget the training schedule. Sick participants are out of control, but other causes are in control. Participants are not allowed to attend due to lack of personnel (no buffers) so the training process will be ineffective and efficient.

- Trainers: Some of causes are due to the trainer is sick, trainer is leaving and miscommunication. The trainers who will be on leave on the day of training sometimes confirm the ability to provide training so that on the day of the training, the trainers do not come. This happens because the trainers forget the day of leave and the staff does not check on the system back because the trainer has done verbal confirmation even by emailing.

- Supervisors: The training participants have been less supervised, resulted in leadership skills are not fully owned. One of them is communication skill. The weekly training schedule is given in the form of softcopy, hardcopy via email and even SMS blasting. However, the training schedule information is not well conveyed to the trainees because the supervisors do not deliver well or even forget to deliver.

- WI Shift: WI for shift is not done well by supervisors. The working process is not in accordance with the standards that have been determined so that shift changes are not done. The scheduling of the participants could be completed by looking at the shift through the system, however the system is not updated and impacts to the error in scheduling. This happens because some supervisors do not understand WI because there is no socialization of WI and lack of leadership in terms of initiative.

The results of the analysis indicate that KPI is not achieved because it is not entirely a mistake of the staff training. Staff training has done in accordance with standards that must be done and even exceed the standards such as calling to each party to confirm directly. While the possibility for participants not attend the training also remains the same. Things that need to be improved are in terms of the trainer, trainee and the involved sections and departments.

- Employee Commitment and Perceptions: Determination of commitments needs to be made for employees. Differences in perceptions about the importance of training causing one side to underestimate the training process. It can be built through the provision of relevant sanctions agreed by both parties. This is supported by the opinion of Sastrohadiwiryo [10] which raises the discipline or commitment to enforce the prevailing rules with the applicable sanctions. Commitment is also made to new employees through the induction.

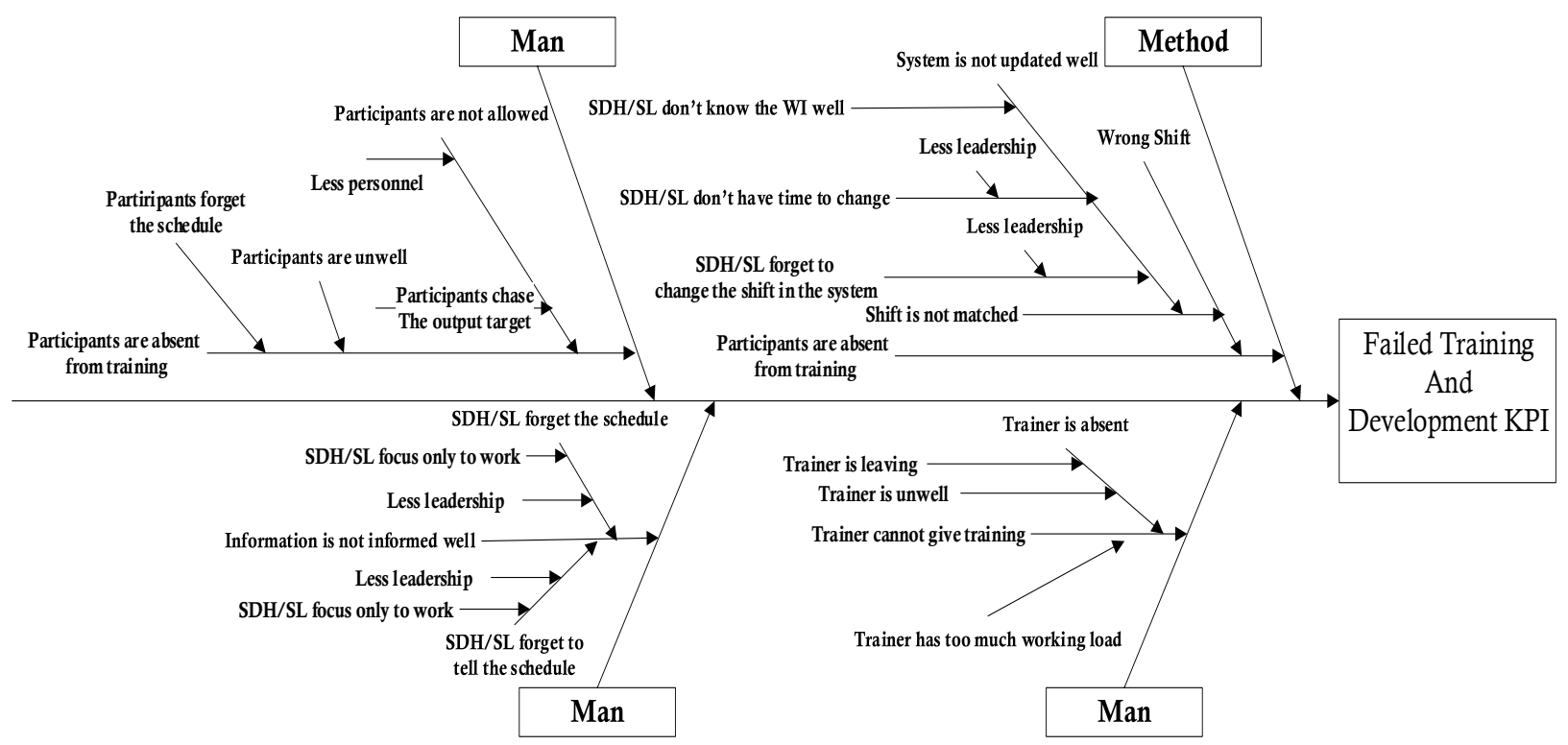

Figure 4. Training and Development Fishbone Diagram 
- Improvement of Workers' Calculation: Improvement workers' calculation relates to the lack of personnel in the field, resulting in overtime activities being enormous. Extremely overtime activities will hamper the training process because participants are not allowed to attend training to help other employees. This also often happens when some personnel are absent due to leave or sick so other employees have to replace the position. The calculation of the number of personnel especially in the production area needs to be re-done so that when the production needs more worker, the buffer is available. This calculation can be done by using Workload Analysis (Arif, [11]).

- Development of Information Distribution: Lack of leadership in communication causes the information distribution process is not working properly. Improving leadership can be done by doing training to superiors in order to communication skill could be ehanced. Information distribution requires a good communication process, consistency of information delivery and selfawareness of the importance of the training process. All of these can be planted through training for both old and new employees. In addition, the method of SMS blasting needs to be changed by doing SMS blasting to supervisors and participants so that all participants are confirmed to get a schedule.

\subsection{Personnel Administration Analysis and Solution}

Personnel Administration is a position that takes care of everything about employee administration. Employees assume that the problems that arise in relation to administrative activities are administrative tasks so that the same problem continues to recur. Therefore, this section is also an important section because it concerns the financial issues either salary or claim. One of the KPIs that should be highlighted is the employee salary recovery process. The recovery process is a process of payment of employee salaries which employee has not achieved previously due to certain errors.
Table 4. Personnel Administration KPI

\begin{tabular}{lllll}
\hline Quartile & Year & Target & Actual & Status \\
Q1-Q4 & 2017 & 20 & 75.17 & Not Achieved \\
Q1 & 2018 & \multirow{2}{*}{30} & 76 & Not Achieved \\
Q2 & 2018 & & 199 & Not Achieved \\
\hline
\end{tabular}

Table 4 shows the personnel administration KPI from 2017 to the first two-quarters of the second quarter of 2018. The target in 2017 is 20 processes and increased to 30 processes in 2018. KPI in 2017 is not achieved with an average gain of 75.17 while in 2018 already indicates not achieved wherein the first two months of the second quartile has done 199 processes. This needs to be analyzed further.

Three biggest causes of recovery process are shift errors, system is trouble and late submissions, as represented in Figure 5. All three of these lead to overtime activities. As for the problem will be divided into two category, methods are related to WI shift both attendance and overtime and how to checklog, machine is related to the tool maintenance.

- Overtime WI: Same with the training process, nonconforming processes lead to disrupted administrative processes where many attendances are not altered so they are not readable in the system. Concistency needs to be improved.

- Checklog: The system fails to read because the checklog process is not right. Employees have a poor understanding of the checklog process, machine characteristics and notifications. In addition, employees also sometimes forget to checklog.

- Machine Maintenance: The checklog machine can also be the cause of the unreadable attendance. The machine maintenance process is not yet clear so this causes the machine cannot run properly. The understanding of machine age has not been understood clearly so that maintenance process is not scheduled properly.

The recovery process is particularly caused by the parties outside the department and ended in the KPI of the personnel

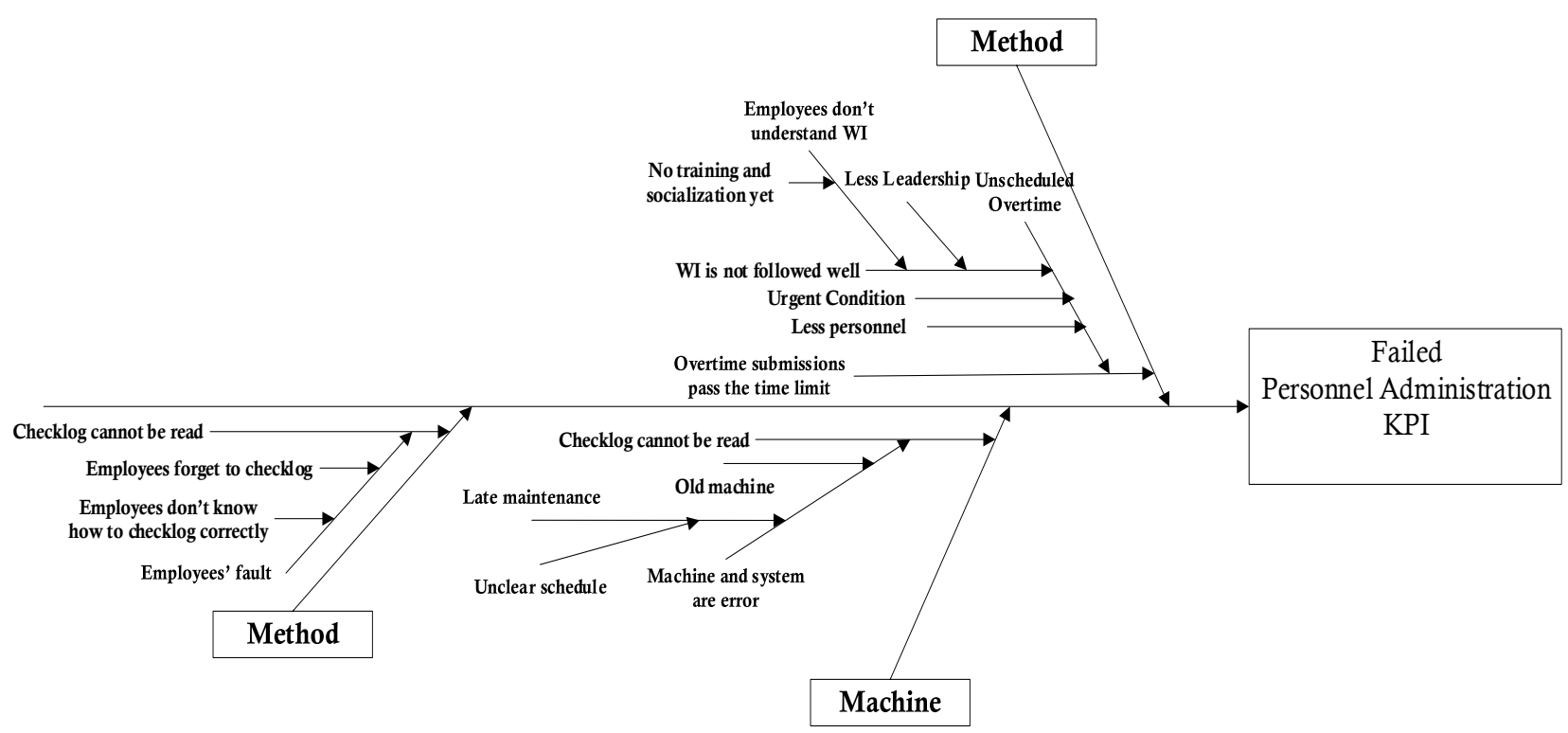

Figure 5. Personnel Administration Fishbone Diagram 
administration is not achieved. The things that can be done are as follows:

- Confirmation of Rules and WI: Confirmation of rules and WIs needs to be done mainly on WI overtime. The overtime process has its own type and classification where each classification has an overtime process submission limit. It has not been implemented properly because there is no clear planning. The supervisors also do not change the system consistently so that the recovery process becomes a lot. It is like the training processes where commitment needs to be invested in old and new employees. Monitoring process also needs to be done.

- Recovery and Checklog Socialization and Training: Knowledge of the recovery and checklog processes needs to be given since it does not yet exist in the induction of new employees and old employees. Employees will be shared a knowledge of the correct way of checklog, tool introduction, notification and the importance of the checklog process and the impact of the recovery process as well.

- System and Machine Maintenance: The maintenance process of the system and machine should be done on a scheduled basis. Scheduled maintenance will reduce the impact on the system and machine. Regular maintenance will be a preventive maintenance. Maintenance process needs to be re-evaluated such as maintenance schedule, checking standard, updating process, etc.

\subsection{Whole Process Analysis and Solution}

HRGA Department KPI needs to be reviewed because almost all KPIs are not achieved from 2017 until 2018 quartiles. The cause of the failure KPI needs to be analyzed from the whole processes.

Figure 6 emphasizes that there are two categories in general that relate to man and method, will cause inefficient and ineffective whole processes. The man part is associated with the employees themselves starting from HRGA Department employees, employees outside the HRGA Department. The methods part is related to the organizational structure of the HRGA Department.
- HRGA Department Employee Competency: One of the causes of the HRGA Department is the competency of the employees. The required competencies are not yet fully owned by employees. This happens due to lack of training or the employee is placed in the wrong position. The incorrect position placement is caused by positions rolling in the HRGA section. For instance, training employee is moved to the recruitment, automatically not all the competencies that should be owned by recruitment employee owned by training employee. The required competencies in each section are also not listed in detail, implies an evaluation and development are needed to be in the job description where the addition of competencies that have similarities between positions such as good administrative skills, time management, and so forth.

- The effort HRGA Department Employee: Lack of employee effort causes KPI not to be achieved. It happened because the KPI is considered as an impossible KPI for employees to be achieved so that efforts are not issued. In addition, employees who have the initiative to solve do not understand how to solve the because the KPI is indeed impossible to be achieved. Though the top managements want employees to have at least an eagerness to solve the problem even if the KPI is not achieved. This is not well conveyed to the employee resulting in miscommunication. The inter-communication between top managements and employees needs to be well developed. Both sides must agree the KPI in terms of responsibilities, calculations, objectives as the KPI is relevant to the employees' duties.

- The leadership of the HRGA Department Employees and Outer HRGA: Another problem related to employees is lack of leadership. It is indicated by lack of effort, eagerness, time management, competency, consistency and communication. This can be seen in the ineffective and inefficient processes that make failed KPI. This also happens to every section of the HRGA Department starting from the recruitment section that is hampered by subcontracting performance which does not comply with the standard. Meanwhile the training and development section is hindered by the communication factor and the personnel administration section is impeded due to the

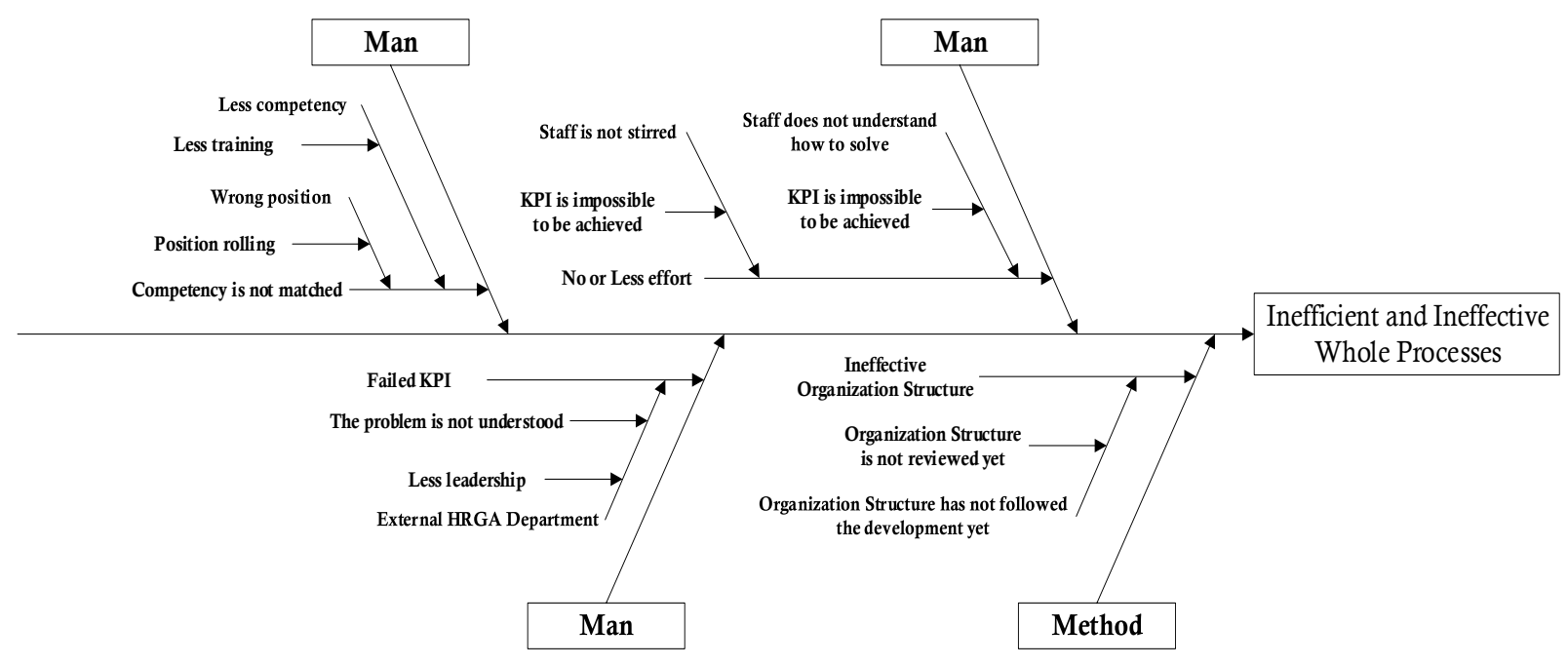

Figure 6. Whole Process Fishbone Diagram 
consistency of shift change. Improvement of the leadership can be done through training activities in the form of classes and assignment and outbound activities. However, the process does not stop there, though the process of the assessment and monitoring should be done.

- Organizational Structure of the HRGA Department: The organizational structure also affects the process. The development of the company must be followed by the development of the organizational structure both in terms of structure and number of employees required. The process at the HRGA Department is hampered because the number of employees required is less. This is because the company is growing with the emergence of new plants but not accompanied by the addition of required employees. The calculation of additional employees can be used as a project because it is related to the company's budget. The employee calculations can be analysed by using workload calculations (Diana and Treasures, [12]).

\section{Conclusion}

The HRGA Department KPIs are not achieved from 2017 until the second quartile in the first two months of 2018. KPI Recruitment is not achieved because the recruitment time of KPI is consumed by non-KPI recruitment time so that the process does not run effectively and efficiently. KPI Personnel Administration is not achieved not because of the recovery process from the HRGA party but from the outside party and the system. KPI Training and Development is not achieved due to absenteeism of the participants. Overall, the KPIs are not achieved due to lack of the effort and eagerness of the HRGA Department employees, undeveloped organizational structure and lack of leadership especially from the outside parties of the HRGA Department.

Solutions that can be given to the recruitment process is subcontractors must be standardized so that the perception will be the same, the recruitment process is not wasted on unnecessary processes. The recovery process required the determination of perceptions and commitments around the recovery process, explaining the causes and those parties must follow the WI. The training process is also given the perception or consideration about the training that the training gives an impact to the company so that the training process will run effectively and efficiently, commitment also needs to be invested in each work.

Some suggestions for the HRGA Department are the need and importance of the communication between top managements and employees regarding the established KPI. Competency improvement and enhancement of leadership need to be executed for all employees of the company.

A practical implication provides the company management with a deep understanding that a KPI must be communicated clearly within the related organization. A reward and punishment system might be established in order to have a realized effort of the employee to achieve its target.

\section{References}

1. Susiawan, S., \& Muhid, A. (2015). Kepemimpinan Transformasional, Kepuasan Kerja dan Komitmen Organisasi. Persona, Jurnal Psikologi Indonesia.

2. Paul, A. K., \& Anantharaman, R. N. (2003). Impact of people management practices on organizational performance: Analysis of a causal model. The International Journal of Human Resource Management.

3. Bartlett, K. R. (2006). The relationship between training and organizational commitment: A study in the health care field. Human Resource Development Quarterly.

4. Simamora, H. (1997). Manajemen Sumber Daya Manusia. Yogyakarta: STIE YKPN.

5. Mangkuprawira, S. (2002). Manajemen Sumber Daya Manusia Strategi. Jakarta: Ghalia Indonesia.

6. Purwanto, M. N. (1991). Administrasi Pendidikan. Jakarta: Mutiara Sumber Widya.

7. Parmenter, D. (2007). Key Performance Indicators: Developing, Implementing, and Using Winning KPIs. Wiley.

8. Tauge, N. R. (2005). The Quality Toolbox. ASQ Quality Press.

9. Jamila. (2012). Sistem Pendukung Keputusan Pemilihan Subkontrak Produksi Sarung Tangan Menggunakan Metode Entropy Dan Topsis. Seminar Nasional Informatika.

10. Sastrohadiwiryo, B. S. (2002). Managemen Tenaga Kerja Indonesia Pendekatan Administratif dan Operasional. Jakarta: PT Bumi Aksara.

11. Arif, R. (2012). Analisa Beban Kerja dan Jumlah Tenaga Kerja yang Optimal pada Bagian Produksi Dengan Pendekatan Metode Work Load Analysis (Wla) di PT. Surabaya Perdana Rotopack. upnjatim.

12. Diana, B. A. \& Harta, R. (2017). Analisis Beban Kerja Pegawai pada Kantor UPBJJ-Universitas Terbuka Bandung. unpad.

13. Kowal, B. (2019). Key performance indicators in a multi-dimensional performance card in the energy sector. IOP Conference Series: Earth and Environmental Science, vol. 214.

14. Eshtaiwi, M., Badi, I., Abdulshahed, A. \& Erkan, T. E. (2018). Determination of key performance indicators for measuring airport success: A case study in Libya. Journal of Air Transport Management, vol. 68, pp. 28-34.

15. Pavelkova, D., Homolka, L., Knapkova, A., Holman, K. \& Pham, H. (2018). EVA and key performance indicators: The case of automotive sector in precrisis, crisis and post-crisis periods. Economics and Sociology, iss. 3, pp. 78-95.

16. Samir, K., Khabbazi, M. R., Maffei, A. \& Onori, M. A. (2018). Key performance indicators in cyberphysical production systems. Procedia CIRP, vol. 72, pp. 498-502. 